BÉHAGUE, Dominique Pareja.

Psychiatry, bio-epistemes and the making of adolescence in southern Brazil. História, Ciências, Saúde - Manguinhos, Rio de Janeiro, v.23, n.1, jan.-mar. 2016, p.131-153.

\title{
Psychiatry, bio-epistemes and the making of adolescence in southern Brazil
}

\section{Psiquiatria, bioepistemes e a formação da adolescência no sul do Brasil}

\author{
Dominique Pareja Béhague \\ Associate professor, Vanderbilt University; \\ senior lecturer, King's College London. \\ Medicine, Health and Society \\ Vanderbilt University \\ PMB 351665 \\ 2301 Vanderbilt Place \\ 37235-1665 - Nashville - TN - USA \\ dominique.behague@vanderbilt.edu
}

\section{Abstract}

Drawing on an ethnographic study in southern Brazil, this paper explores how therapists' attempts to "resist bioreductionist" pharmaceutical use both succeed and crumble. Using a comparative framing, I show that pharmaceuticalization can become an anesthetizing "lid" that interacts with young people's polarizing micropolitics and is an outgrowth of multigenerational medico-political family histories. This lid, however, is not air-tight and exceptionalities are born out of these very same histories. I argue that both pharmaceuticalization and exceptions to it emerge not through "resistance" to biopsychiatric logics but from the transformative possibilities that the patterned co-production of social, political, and psychiatric life affords.

Keywords: Brazil; pharmaceuticals; bioreductionism; epistemology; history.

\section{Resumo}

Baseado em um estudo etnográfico no sul do Brasil, este artigo explora tentativas frustradas e bem-sucedidas de terapeutas em uma "resistência biorreducionista" a medicamentos. Comparativamente, busco mostrar que a farmaceuticalização pode se tornar uma "rolha" entorpecedora que interage com a micropolítica polarizante dos jovens, e é fruto de histórias familiares médico-políticas em várias gerações. Contudo, essa rolha não está bem vedada, dando margem a exceções nessas histórias. Acredito que a farmaceuticalização e as exceções não surjam da "resistência" à lógica biopsiquiátrica, mas sim de possibilidades transformativas na coprodução padronizada da vida social, política e psiquiátrica.

Palavras-chave: Brasil; medicamentos; biorreducionismo; epistemologia; história. 
A clinical concept of adolescence is, according to some historians, nearly two centuries old (Gillis, 1981). Formally canonized at the turn of the twentieth century by psychologist Stanley Hall (1904) in his book Adolescence, the transition from childhood to adulthood has long been described in psychodynamic theory as a period of "storm-and-stress" that garners psychological turbulence as well as developmental creativity and personal transformation. Over the past few decades, however, the growth and globalization of cognitive behavioral sciences, biological psychiatry, neuroscience, and public health epidemiology have overshadowed these psychodynamic framings and infused them with a psychiatric "risk behavior" model centered on diagnostic categories such as attention deficit hyperactivity disorder, learning disorders, conduct disorders, and depression. As social scientists have now amply shown, the rise of these diagnostic categories is typically associated with concomitant rises in pharmaceuticalization in the United States, United Kingdom, and elsewhere (Healy, 1997).

In Pelotas, southern Brazil, where I have been conducting ethnographic fieldwork since the mid 1990s, biopsychiatric and pharmaceuticalized framings of adolescence are gaining traction in antithetical juxtaposition to local experts' long-standing commitment to psychodynamic psychiatry, social medicine, and the establishment of a universally accessible communitybased social psychiatry. Many psychiatrists consider current rates of licensed psychotropic medication use among youth to be unacceptably high. They point to an unsettling extension of neuro-pharmaceuticalized framings to a range of "adolescent health" problems - such as alcohol and substance use, violence, and teen pregnancy - that they argue should be understood first and foremost not as "psychiatric disorders" but as outgrowths of poverty and inequity. I was often told by leading psychiatrists that therapists who are unable to "resist" the pharmaceuticalization of social problems by employing psychodynamic principles too superficially, writing prescriptions when unnecessary, or failing to transition patients off medications when danger has passed are unwilling pawns of larger biopsychiatric and economic forces. This is not to say that the ideals of social psychiatry are never realized. As I have shown elsewhere, several low-income youth I knew hoped for and experienced deeply transformative therapeutic encounters that spoke not of biology, disease or medication, but of life stories, injustice, discrimination, and the potential for transformation that "adolescence" endows (Béhague, 2009). Yet on the whole, current trends point to a conundrum: modalities of bioreductionism are emerging through complex indirect routes despite the stated intentions of a vast number of clinicians and despite the fact that languages of the brain and psychiatric "disorder" are not readily used either in the clinic or everyday life (Béhague, 2015).

In this paper, I explore this ethnographic conundrum by situating the rise of bioreductionist therapeutics in ways that point to the importance of social-structural and historical forces, and of the social and political patterning of social life through time. I draw from long-term fieldwork, initiated in 1997, that took place during the period in which biopsychiatric approaches first began gaining contested traction in Pelotas. I conducted fieldwork with an array of experts ( $\mathrm{N}=92)$ and a group of 96 young people selected from the 1982 Pelotas birth cohort study, visiting them repeatedly from ages 15 to 25, and speaking also with their parents, siblings and sometimes extended family members. ${ }^{1}$ Having watched these young people experience varied therapeutic trajectories as they underwent "adolescence," I have become convinced that epistemic "resistance" to biopsychiatry is not the primary force 
accounting for the therapeutic innovations that map onto the ideals of social psychiatry. Nor do I think that the intentional rise of a coherent bio-episteme in psychiatry is core to the recent rise in pharmaceutical practices. Moving beyond a type of analysis that gives primacy to expert formulations and routines of care in the clinic, I employ a comparative framing that explores how different adolescent therapeutic trajectories - some more chronically and problematically pharmaceuticalized than others - become more or less meaningful, valued, and enacted over time. I analyze these heterogeneous trajectories in relation to the broader histories within which they have become socially, economically, and politically patterned, even structured.

In appealing to structures and patterns, I refer not primarily to how "social and economic determinants" account for the way emotional distress and forms of care are distributed in society, though I will show that this is certainly an insightful place to start. Instead, I show how these distributions are born of micro-level social, moral, economic, and aesthetic distinctions and differentiations that emerge in small scale iterations through everyday practice over a long period of time (Bourdieu, 1984). Though such micro-iterations often coalesce into social structures that are very powerful indeed, I do not consider these structures to be deterministic. Thus, my analysis seeks to shift away from the question of how science and the clinic "construct their objects" - in this case, adolescent morbidities and bio-epistemologies - and towards one that explores how these "objects" are co-produced with social life, situated in a bidirectional mutually constitutive relationship with the everyday (Jasanoff, 2012).

In giving greater attention to the "everyday" aspect of this co-production, I also seek to understand how transformations can be engendered from within and through the structures of social life. In this sense, I underscore the ways in which therapists and young people come together as bricoleurs, to use Lévi-Strauss' (1966) productive concept, improvising with an array of "objects" - ideas, metaphor, symbols, practices - that are "good to think with" (cf. Douglas, 1986; Turkle, Papert, 1990). The most productive of these objects are the most contested and include: clinical notions of adolescence, psychiatric diagnoses, arguments for and against biomedical reductionism, and discourses on generational change and cleavage (Durham, 2004). In following the everyday life of these bricoleurs, I endeavor to show how the desire for alternative forms of socio-political personhood can "crack through apparently rigid social fields and serve as the engine of becoming," altering social life in enduring ways (Biehl, Locke, 2010, p.323).

Set within this theoretical framing, the empirical material presented in this paper proceeds in four parts. The first two parts show that pharmaceuticalization can at times become (1) an anesthetizing lid that (2) interacts with and is fueled by young people's polarizing micro-politics. A third section explores how both pharmaceuticalization and micro-political positionalities are reflections of (3) tightly woven inter-generational medico-political histories. Attending to the question of how opportunity-filled "cracks" in social patterns arise, a final section underscores the instances in which the pharmaceutical lid (4) is not air-tight. Trend-bending exceptionalities, I further argue in this section, are born out of the very same medico-political histories that produce pharmaceuticalization, and they emerge not through "resistance" to biopsychiatric logics and not in spite of emerging clinical theories of 
adolescence, but because of the transformative possibilities that the patterned co-production of social, political, and psychiatric life affords.

\section{A pharmaceutical "lid"...}

The vast majority of psychiatrists, psychologists, and social workers I knew at the time of my fieldwork avidly debated the emerging globalization of "Anglophone biopsychiatry." Psychiatrists often told me, for example, that newly emerging diagnoses for adolescents, such as conduct disorder and attention-deficit hyperactivity disorder, are "socially constructed" symbols of Anglo neuro-psychiatry, canonized in diagnostic manuals and backed by industry. Many worried that chronic medication-use can hinder substantive improvements in a patient's emotional state and become a mere "therapeutic lid" that keeps the conditions accounting for mental strife under wraps, simmering but still wounding. One eminent psychiatrist told me that in such cases patients can easily enter into a "medicated holding pattern" that "anesthetizes" them and creates "distance from affect, becoming little more than a mordaça [muzzle, restraint]." This does not mean that medications are not prescribed and considered useful. However, most therapists consider "proper" medication use to be temporary and subservient to the work of reflection (Sousa, Abuchaim, 1994). Indeed, as was the case in US psychiatry of the 1960s and 70s (Healy, 1997), at the time also broadly psychoanalytic, many therapists in Pelotas understand the pill's efficacy to reside not in its inherent chemical ability to remedy the biological causes of mental distress, but rather in its ability to stabilize symptoms and synergistically open the patient up for introspection and social-personal transformation.

This therapeutic ethos has emerged at the cross-roads of various cumulative socio-historic forces. Psychoanalysis, imported and studied in the early twentieth century by upper-class Brazilian intelligentsia, has been the object of considerable critique in Brazil; claims of its tendency to be individualizing, to neglect the material and economic conditions of distress, and to indirectly encourage the psychiatric hospitalization of patients deemed "incapable" of deep analysis have been at the center of such critiques (Costa, 1976; Tenorio, 2002). Yet in Brazil, psychodynamic approaches have not been wholly marginalized in favor of either cognitive behavioral framings or neuroscientific psychiatry as has occurred in the United States and United Kingdom. Instead, core psychodynamic principles, such as the emphasis on the interplay of conscious and unconscious forces and the power of introspection to reveal the social and personal roots of malaise, have been reformulated for use in the public sector and with patients of all social classes. This social psychiatric reformulation gained institutional backing after the end of Brazil's most recent dictatorship (1984) and with the constitutional revision of 1988, which set the groundwork for psychiatric de-institutionalization, community mental health and the wide-scale decentralization of Brazil's health and education systems (Tenorio, 2002). Throughout the 1990s, mental health care services were increasingly integrated into primary care clinics and schools situated close to or in peripheral "shantytown" communities. With $60-70 \%$ school failure rates in some public schools, the pool of students for potential referral to specialist psychological services is large. In smaller towns in the more developed southern regions like Pelotas, where access to services is good, this experiment in 
social psychiatry has achieved remarkably high utilization rates - upwards of 30\% among under-20s in one survey conducted in 2001 (Béhague, 2004).

Because psychiatric de-institutionalization is known to increase pharmaceutical use, psychiatrists leading these reforms have avidly debated the gulf that they know can separate the ideals of social psychiatry from the realities of its implementation. To preempt this gulf, some practitioners have explicitly broadened the definition of "therapy" to include group discussions, community outreach, development of better leisure opportunities in low-income neighborhoods, and peer-to-peer support. Others underscore the fact that by focusing on child and adolescent development rather than pathology or diagnosis, therapists can remain close to the ideal of social psychiatry and vigilant about the perils of undue medicalization. Such vigilance is supported by long-standing theoretical trends in other intersecting fields: most notably, Marxist influences in social medicine and epidemiology, as well as post-dictatorial education reform which rekindled Paulo Freire's (1990) "critical pedagogy," emphasizing a form of education that eschews memorization and conformity and nurtures, instead, "critical consciousness."

What, then, of the effects of this changing landscape on patients' lives? The succinct answer: the first phases of my ethnographic and epidemiological observations suggested the existence of two main kinds of "adolescences" within which two kinds of pharmaceutical use evolved. In the first, medications became a temporary vehicle to personal betterment and these kinds of adolescences tended to emerge more frequently among upper-middle class and upwardly mobile families. In the second, medication-use became chronic, placating and prone to latent bio-theorizing - precisely the "pharmaceutical lid" that local therapists are keen to avoid. ${ }^{2}$ Unsurprisingly perhaps, this second kind of trajectory was concentrated among youth of the lowest socio-economic echelon. How exactly did these two diametrically opposed forms of adolescent development and medication-use emerge?

The first kind of adolescence often began with reference to difficult life circumstances and was typically situated in comparatively loose developmental "diagnostic categories" such as crises, trauma, anxiety, and distortions of identity and self-image. In this framing, the normalization of symptoms and the sanctioning of a slower developmental pace were critical. Both therapists and patients often adopted therapeutic languages that recall Stanley Hall and Erik Erikson's notions of adolescence as a "moratorium" and period of noncommittal experimentation (Cairns, 1998). When psychiatrists gave these young people prescriptions, they typically explained this to be a temporary response to severe symptoms such as suicidal thoughts. Because most of youth were, like their therapists, somewhat skeptical of medication use, they entered into what can best be described as a medicated psychodynamic journey infused with the optimistic notion that the end of adolescence would also bring a reduction in distress. For therapists and patients alike, adopting a fluid definition of the "end" of adolescence based not simply on age but on the subjective experience of maturation was very useful. Where symptoms persisted, adolescence was said to not yet be "resolved" and additional support mechanisms both in therapy and through family and school were put into place. In this therapeutic enactment, withdrawal of medication marked the end of adolescence and the resolution of symptoms, and thus became as, if not more, symbolically important than the sanctioned reprieve it enabled. 
Significantly, I found this type of adolescence emerging among a handful of youth from considerably deprived backgrounds whose families were in the process of achieving upward mobility. Given the added difficulties faced by these young people - e.g. intense poverty, school failure, social conflict, exposure to violence in the neighborhood, and at times drug use and abuse - the "normalizing" aspect of a psychodynamic understanding of adolescence was particularly motivating, since an adolescent "moratorium" gave these young people ample time to "get better" while allowing them to avoid feeling stigmatized. Therapists consistently nurtured a multi-pronged approach focused on school completion, skills needed for employability, and creating a fulfilling social life. Integral to these young patients' ability to eventually shift from medication use to talk therapy only, and then no therapy, were improved life circumstances and a significant amount of parental and wide-ranging formal and informal support from teachers, religious healers, leaders of neighborhood associations, and friends. Many of these young people went on to pursue careers in psychology, social work, teaching and other professions where helping others to "develop" to their fullest potential was core to their own sense of personal-professional achievement. In this framing, the capacity to avoid long-term "dependency" on psychotropic medications was transformed into self-vindicating proof of the merits of psychodynamic approaches and the power of the young person's adolescent transformation.

The second kind of adolescence typically unfolded in the absence of upward mobility and multipronged support. Though many of the low-income youth I met had eagerly awaited a forward-looking and emancipating "adolescent experience," their lives rarely unfolded as such. Over time, the therapeutic practices and languages they encountered became progressively centered on a more pathologizing child-oriented framing with more explicit references to potential diagnoses such as inattention, behavioral misconduct, poor impulse control, and externalizing problems. With time, these youth began to be understood and talked about by parents, teachers, and school psychologists as being "stuck in time" - acting in ways that were too childlike for their age. As a few psychologists explained, when different "lines" of development - cognitive, emotional, sexual - evolve in a disjointed way, some more quickly than others, a truncated or "arrested" form of development ensues, rife with anxiety, ageinappropriate emotions, recalcitrant behaviors, and even aggression. This theory was not ascribed to by most psychiatrists and academic psychologists. Though it has a long history in medicine and psychiatry (Cairns, 1998), when I inquired in the field, several psychiatrists I spoke with explained that it represented an antiquated form of Freudianism emerging from the school of ego psychology and the works of Anna Freud and Heinz Hartman, amongst others. In the school environment, however, notions of developmental regression abounded as these young people's adolescences came to be understood not via Stanley Hall's normative "storm and stress" but rather as a failure of the poorly-developing ego.

Though psychotropic medications had been prescribed during these young patients' schools years, most of them stopped taking their medications after a short time, not because they felt better, but merely because of overarching therapeutic disappointment. And, though these young people had often felt vilified by early interventions, especially by the kinds of diagnostic categories they encountered, many returned to psychological or psychiatric care in early adulthood, bearing the weight of a difficult-to-challenge language 
of psychological passivity. Most arrived with severe enough problems - suicidality, drug abuse, and/or paralyzing nerves attacks (Duarte, 1986) - that medications were prescribed again, and this time, taken for longer durations. Now adults, patients recounted how they needed to "work hard" to accept their adult responsibilities and resolve the lingering "stresses" of their unresolved adolescences. They sought in therapy the cultivation of the self and social acceptance. Waiting for adulthood became the bare minimum of agency that many of these young could muster, even when psychiatrists sought to distance themselves from the "adaptationist" tendencies of ego psychology and even when they posited the central role of poverty, migration, truncated schooling, drug use, and violence in producing morbidity. Though therapists justified medication as a necessary course of action by appealing to the need to avoid further deterioration, several also explained that the use of medication for such "complex" cases has been woefully under-problematized with regard to potentially damaging long-term consequences.

These "therapeutic stagnations," as one therapist described them, became compounded when patients attempted to implement the hoped-for transition from drug therapy to talk therapy, often with little success. Here, I began to see the first inklings of the kinds of chronic medication use that are typically associated with the post-1980s biomedicalization of North American psychiatry. Blurring the distinction between symptom, side-effect, and withdrawal effect, a new "post-pill" context for the analysis of symptoms emerged - one in which both therapists and patients began to make reference to clearer diagnostic categories, such as depression, and to a more immutable understanding of their "brains" and neuropsychiatric cause. Even therapists who were initially adamant about avoiding such interpretations modified their views over time, as they began wondering in moments of heightened professional frustration if their patients' inability to engage in psychodynamic analysis might be linked to their somatizing modes of relating to social hardship, underpinned as these were, some speculated, by the destructive effects of grinding poverty.

In another paper, I have explored what these two interlinked "therapeutic journeys" can tell us about how knowledge is produced (Béhague, 2015). I have argued that although biomedical rationales are beginning to form, what is occurring in Pelotas is not at all similar to the kind of pharmaceuticalization that is propelled by neurobiological framings of adolescence and broader theories of the "chemical brain" as has been the case in the United States. Rather, pharmaceutical responses are embedding themselves at the limits of socialpsychodynamic attempts to redress severe social problems. It is primarily at these limits that biomedical theorizing is seeping in, through the "back door" of post-pill somatic experiences. It is mostly during these post-pill moments that psychiatrists and patients begin to produce incipient biopsychiatric logics to explain either why psychoanalytic therapy is so successful in "resisting" bio-reductionist pharmaceuticalization or to explain why patients accept and seek neuro-reductionism and "allow" pharmaceuticalization to become chronic. This "backdoor" bio-theorizing is not just a "logical" response to therapeutic frustrations. It is also a response to the moral discomfort that is produced when therapists confront what these two adolescent types could be taken to signify about the history of classism in Brazil. As scholars have argued, Brazilian psychiatry, long infused with a two-tiered system - psychoanalysis for the rich and psychiatric hospitalization for the poor - seems to be struggling to shake a host 
of bifurcations entrenched in an early twentieth century Freudian aesthetic that juxtaposed upper-class intellectualism against the "retrograde" psyche of the underclass (Costa, 1976; Duarte, 1999-2000).

\section{...interacting with polarizing micro-politics...}

At the same time, to suggest that the pacifying pharmaceuticalization of adolescence is an outgrowth of historic expert-driven classism is too partial a framing and too vested in a teleological rendition of how clinical expertise shapes life. How might a broader comparative analysis of the incremental emergence of chronic bio-oriented pharmaceuticalization unsettle this teleological assumption? In answering this question, I began to view "the clinic" not as a starting point, but as a midway point, or recurring stopping point even, in much larger social, clinical, political, emotional, and economic trajectories.

Pharmaceuticalized trajectories began, quite ironically, with young people's search for radical change in their lives and communities, and with the hope that therapy might provide them with support in this search. This position was somewhat unusual. Psychologists were most often seen as disciplinary figures, no different than teachers or school directors. Though mental health care utilization rates are high, many low-income youth - the vast majority in fact - had initial interactions with school psychologists that were conflict-ridden and overshadowed by, as young people saw it, psychologists' denigration of their "bad" behaviors. While some young people followed up on referrals to psychiatrists who prescribed medications and offered talk therapy, such offerings were of little therapeutic interest. For some this experience became the tipping point for abandoning school - and thus therapy - altogether.

In contrast, youth who stayed in school and returned to therapy, despite feeling reprimanded and judged by teachers and psychologists, were highly driven. They sought not upward mobility per se but to change the conditions leading to their distress and the world in which they lived. They actively imagined and wished for a different social life, one less infused with social hierarchies and discrimination, and they resisted the status quo in almost every facet of life. However, as they plucked up the courage to actively engage with and try to change the world - staying in school, establishing friendships that break class divides, and at times being quite vocal about the injustices of being among the disenfranchised - they also exposed themselves to social conflict and stigma. Rather than recoil and drop out of school at such junctures, as many youth do, they reacted by becoming increasingly polarizing in their way of being, engaging in a form of "micro-politics" that fostered frustration, emotional turbulence, and eventually, the desire for pharmaceuticalized silence.

Alex, a case in point, was sent several times to the psychologist, as well as to the director's office, for "aggression," "inattention," and poor school performance during his childhood and teen years. Though he conceded to needing help and always dutifully spoke to the psychologist when referred, his overall experience was imbued with conflict. "They can't write on my card that I'm aggressive," he explained after one such referral. "I admit it. With teachers, if they yell at me, I find it hard to keep still. It's very hard for me, the blood rises to my head, and nothing can stop me. I don't use such bad language, and now I'm better, I'm not like that anymore, but shit, there are some teachers that really offend you, that leave 
you [feeling] completely crazy." He felt disheartened with the psychologist's perennial focus on his behaviors and he wished she would rectify the real reason for the teacher's "hatred of him," which in his view was linked to preconceito (prejudice). He questioned the ways adolescents were always described as "impulsive" and "irrational," and once insinuated that such framings were in fact reserved for "shantytown kids" only.

Nevertheless, Alex stayed in school and returned to therapy. At times he spoke hopefully of the transformations his adolescent phase might bring - a framing the school psychologist had imparted to him. Over time, however, as he shared his hopes with me, his focus shifted to the social: to an imagined social world that was peaceful, regular, predictable, and "not so full of gente que não vai com minha cara [people who don't like me]." As Alex neared his 18th birthday, the age of compulsory military service in Brazil, this social-emotional "imaginary" gained force through detailed discussions of how military instruction might be helpful. While most young men find ways to be exempted from service, I discovered a substantial number of young men like Alex who looked forward to conscription and even worked hard to pass the "entrance exams." ${ }^{3}$ Alex's father had served in the military during Brazil's dictatorship. Like others of his generation, he was nostalgic for the "law and order" of these times and undoubtedly played a role in shaping Alex's views of military instruction. In fact, this intergenerational connection was common.

Yet young men like Alex were different from the older generation, for they spoke of military life not in terms of the acquisition of adulthood and masculinity, as their fathers did, but in the therapeutic language of psychological and social well-being. Several postulated that military training might guide them towards the self-cultivated and "resolved" adolescence that they had come to feel was necessary but also out of reach in the context of formal education. For most, this included finding a way to lessen their anxieties and emotional "attacks" and stop their "adolescent vices," such as smoking, drinking, and drug use. They imagined how the military might "work" by underscoring its predictable institutionalized life-world, its equalizing and homogeneous social structure, its provision of shelter from the troubling inequities and injustices that many felt were at the heart of their troubles. "In the barracks you learn to viver direito [live correctly]," Alex explained to me, "You learn respect. You can go into the barracks practically illiterate, and they'll make you capable, ignite your interests. It clears your mind... It's almost like a boarding school, a place where there are many people and where everyone helps each other." The link between frustrated psychological interventions and an imagined military therapeutics was one that I found time and again in a number of young men (Béhague, 2008). Each time Alex, for example, was sent to the school psychologist by his teacher, each time he became frustrated with the psychologists' urgings, each time he felt disparaged for his "behaviors" and marginalized status - each of the instances became an occasion for him to cultivate a desire for the social and emotional instruction and "protection" of military training. Significantly, Alex also imagined military training to be a form of care that would somehow work through the collected routinization of life, and not through introspection: "Here [at home, in school]," he explained in no uncertain terms, "there is always too much thinking."

The vast majority of the time, such adolescent imaginings had no bearing on how these young men's adulthoods actually evolved. Most who had been keen to enlist did not end 
up serving, and even if they did, their year of military service did not provide them with the totalizing therapeutic panacea they had expected. Though they stayed in school longer than most of their peers of low socio-economic backgrounds, they eventually dropped out, usually with five to seven years of education, minimal job prospects, and a heightened sense of hopelessness. Yet, having experience the beginning of an adolescence that was clearly framed in psychological language, no matter how contested, most returned to therapy at their local primary care clinics as young adults. They arrived in clinic as young adults, more intensely frustrated than ever before, rejecting the injustices of the world around them, and with life situations that easily led to the chronic and medicated holding-pattern local therapists so wanted to avoid.

By the time Alex sought help at his local clinic and was referred to a psychiatrist, he was living with the mother his newborn child in a shack at the rear of his father-in-law's plot of land. He was 21 years old and with only five years of education, his job prospects were slim. He spent hours watching television and on some days was barely able get out of bed to work the odd construction jobs his father found for him. This deep lethargy was interspersed with moments of angry fervent debate about the plight of the poor and Brazil's corrupt government. The cycle of lethargy and impassioned politics intensified each time I visited him. When Alex was given a prescription for an anti-depressant, he initially viewed the pill not as medication that would fix a psychiatric disease or problem with his brain, but rather as an opportunity for momentary respite, to rest and muster the energy he wished he had to transform his life. As his psychiatrist explained, the anti-depressant would simply be a stepping stone to more important life changes. Yet what ensued was a longer medicated journey in which the distinction between "symptom" and "side effect" become blurred and, as described in the previous section of this paper, which proliferated into a confusing "post-pill" mass of bodily "data" that fed a reductionist ethos. As Alex posited by his 22 nd year, "I can get very anxious. I get nervous. It attacks my stomach and gives me headaches. The only way I can control myself is with the remedinhos [little pills]. I also withdraw, to the maximum. I can combat the sensations, but only if I lock myself away, speak as little as possible, keep myself still." Like other such young men, Alex never managed to stop taking the little remedinhos, but each time he tried, his heightened anxiety fueled a reductionist bodily and somatic focus.

What is at play here is not straightforward bioreductionist classism, nor even the relief of culpability that is often said to be at the heart of patients' desire for simplistic brain-disease models of psychiatric morbidity and pharmaceutical quick-fixes. Rather, leading up to Alex's desire for the pacifying quick-fix of the pill were years of incrementally intertwined class conflict, school life, psychological interventions, emotional upheaval, polarizing politics, an ardent desire for radical societal change, and ultimately, the desire for both withdrawal from society and a biomedical language within which to operationalize that withdrawal.

The micro-iteration of personal politics, social engagement, and emotional exhaustion became clustered in other kinds of social-personal life trajectories. Here I would like to underscore the trajectories of young women from low-income backgrounds who came into contact with school-based psychological services for issues relating to sexuality and reproductive health (Heilborn, Brandão, Cabral, 2007). The psychologization of sexuality has 
intensified over the past decade with the growth of public health initiatives aiming to prevent teen pregnancies not only through sex education but through a specific focus on the psychiatric and developmental causes and consequences of teen sexual behaviors. In these initiatives, problems of sexual maturation and unwanted pregnancy are being recast as problems of developmental impulsivity, and as typically "co-morbid" with inattention, low scholastic achievement, behavioral misconduct and eventual depression. In another publication, I have explored the paradoxical ways in which these initiatives are gaining ground despite therapists' explicit desire to avoid pathologizing the social terrain of teen pregnancy. I argue that what lies behind the rise in these initiatives is not the formalization of neuropsychiatric models in science and policy. Rather, these initiatives and languages are arising in small often unintended increments as teachers, psychologists, and psychiatrists grapple to find ways of responding to the publically defiant gendered practices of "proto-feminist" young women (Béhague et al., 2012). What I did not explore at the time of that publication was the way these young women's micro-politicized life trajectories, like Alex's, so consistently led to routines of care that fed into a more chronic form of bio-pharmaceuticalization.

Rosane was one such woman. Like other youth, she had begun her teen years quite critical of the world around her. "It's not fair," she once told me after receiving a referral to the psychologist. "They always peg 'us'. All this talk they want, it's just to tell us what to do, what is wrong with 'us' [shantytown] kids ... Adolescence? Ha!" she continued, "They talk about adolescence, [but] that doesn't exist [for us]." She often insinuated that adolescence was a luxury only rich kids could afford and was quick to point out that teachers seemed to refer "shantytown girls" for psychological interventions more than students of higher economic standing, even when the behaviors and problems at play were largely the same. When Rosane began experiencing "nerves attacks" in her mid-teen years, she clearly stated that her problems related not to "adolescence," "misconduct," or "behavioral impulsivity," but to her social and economic milieu.

Debates over diagnosis often played a more intense micro-political role for young women than it did for young men. Women such as Rosane did not simply feel "stigmatized" or inappropriately labeled by psychological language. On the contrary, many were subtly boastful of the fact that the school psychologists had told them they might have "behavioral problems" or "inattention." Behavioral diagnostic categories such as these are generally associated with boys' problems and they depart significantly from the typical "body image," "difficult life events," and "social relationship" issues that beset most girls of all economic strata. For women such as Rosane, embracing this diagnostic "masculinity" became a "good to think with" object that rendered her gender politics publically visible and powerfully controversial. More than once, for example, Rosane defiantly told me about the large number of boyfriends she had already had, and she once recounted having boldly asked the school psychologist, whom she visited on occasion, why boys were allowed to date many girls without question. Though school therapy did at times open up a space for such contestation, ironically, the more young women like Rosane were exposed to the notion that their dating behaviors and emerging sexuality were underpinned not by romance but by immaturity and impulsivity, the more their desire to affirm their normality and reject diagnostic routines gained momentum. As I have shown elsewhere, this momentum often encouraged women to move closer toward 
what they experienced the ultimate act of prideful working-class defiance: leaving school altogether to become teen mothers. While "teen motherhood" can in many instances be an emotionally and socially stabilizing life-event, for young women who embodied their personal politics in this way, the transition to motherhood was often rife with anxiety and self-doubt (Béhague et al., 2012).

By age 22, Rosane had left school, had no job, no serious boyfriend and no prospects of marriage. With troubled family relations, she did not feel as though she could continue living at home. In the three previous years, she had spent time living on the streets, had become a victim of violence, had witnessed her first boyfriend die, and had struggled intermittently with drug abuse. Because of Rosane's prior interludes with psychological interventions, no matter how contested, she sought this form of care again. Like Alex, she ended up in a psychiatrist's office, accepting medication under the weight of chronic and debilitating nerves attacks and depression. "My depression," she told me in her 23rd year, "appeared for the first time in adolescence and came back with hypertension. I had to get back onto the anti-depressants. I'm now trying to stop again, slowly, but I notice it immediately when I stop taking them, things aren't right, there's something there." At times she linked that "something there" to her difficult life and the traumas of her "lost childhood," while at other times she compared it to something more physiological, akin to her rising blood pressure. Rosane often expressed a desire for more meaningful therapy and a deeper understanding of the origins of her distress, as did her therapist. Yet even then, she used corporeal terms to imagine how talk-therapy might help her to "expel the stress and loosen her body." Ultimately, she resigned herself: "I know people who take several medications regularly: one for nerves, one to sleep, another for depression. It's complicated. I suppose we will all reach the point of having to take those remedinhos all the time."

This kind of pharmaceuticalization defies all that social psychiatry stands for. Unlike upper class and upwardly mobile youth for whom "temporary" pharmaceutical-use became a powerful self-vindicating symbol of their hard work and psychological strength, Rosane and Alex ended up in clinics as young adults, battered, bruised, and tired, longing more for the quick fix of a pill than the deeper changes they had initially sought. Alex's hope for a socially equalizing military therapeutics no doubt seems far removed from Rosane's gender politics. But in taking a comparative step back, their life trajectories share a common core: the exhausting micro-political search for a different type of society in which to live.

\section{...over tightly woven inter-generational medico-political histories...}

I did not know Alex and Rosane as children. Yet as they entered into routines of chronic pharmaceuticalization in adulthood, they began talking more about their childhoods. The narratives they produced were not prototypical psychodynamic narratives of trauma and the re-making of the self. Rather, in struggling with their adult symptoms and specifically with unsuccessful attempts to stop taking their medications, latent concerns with a possible underlying childhood pathology surfaced. In fact, I soon found out that these concerns were resurfacing. Nearly always, their stories featured episodes of emotional turmoil from their childhoods in which a bodily, somatizing, and even biologizing orientation to their problems 
had been posited by their mothers. Rosane, for example, began remembering how her mother used to talk of her "empty memory banks" in her brain when it came to her frustrations with school work, and Alex recounted how his mother had once wondered if his fits of rage might be linked to a mild form of epilepsy. Both remembered theories of their "inattention" being linked not simply to disobedience, but to potential cognitive "malfunction." Even though these passing theories were often discarded - which explains why they did not feature centrally at the time of adolescence - in the context of the "post-pill" struggles that emerged in adulthood, they were readily recalled.

By asking more about this and going back to my field notes, I began to notice just how consistently these children's mothers had played a key psychologizing role in their children's early years. Many had sought help from pediatricians, general practitioners, and psychologists when their children were 7, 8 and 9 years old, often to little avail. They were ambiguous about the merits of therapy and unsure whether the condition at hand was physiological, neurological or indeed emotional. They recounted how uncertain they had felt about how to address their children's problems, at times taking them to specialists while at other times rejecting medical help altogether and resorting to religious practice and stricter parenting techniques. Most often, they seemed to settle on the use of somatic and bodily terms - more so than those referring to development, cognition, or mind - to describe the early manifestations of their children's problems. A language of fits, rage, fainting spells, bodily heat, rising blood, and stomach aches dominated and, I surmised, set the stage for over-layering on top of these somatic complaints the clearer diagnostic language of "inattention" and "impulsivity" that these children went on to encounter during adolescence in school. Thus, young people such as Rosane and Alex had been socialized to understand, embody, and accept a clinical language of somatization well before they came into direct contact with school psychologists. I began to wonder if teachers selected children such as Alex and Rosane for psychological referral not simply because of need or classist attitudes, but also because these children had been reared in ways that created a latent interest in and acceptance of psychological and psychiatric intervention. ${ }^{4}$

Going further back in time, I found that Alex's and Rosane's mothers had, like many women of an older generation, suffered from "nerves attacks" during their youth, either before motherhood or as young mothers. The vast majority were migrants who had come to the city with their parents in the 1950s and 1960s in situations of intense poverty and duress. Several had been hospitalized, mostly in the 1970s, still during the era of hospitalbased psychiatry. After hospitalization in what despite psychiatric de-institutionalization are considered to be institutions that still infringe upon basic human rights, they became weary of biomedicine, shifting back and forth between the care of the medical establishment and that provided by religion, usually either evangelism or Umbanda. Yet they continued to seek medical and psychiatric care over the years in no small part because many had become addicted to benzodiazepines and all seemed convinced of the chronic nature of their condition. Even for those who had not been hospitalized, nerves attacks for women of this generation came to be synonymous with seeking and receiving benzodiazepines and hypnotics (Scheper-Hughes, 1992). Despite a generalized and explicit attempt among psychiatrists to call attention to the abuse of benzodiazepine-use, therapists have told me 
that women of this generation arrive at clinics with a single and persistent request - that they be given something to calm their nerves.

Quantitative analysis of the Pelotas 1982 cohort data found that the mothers who regularly used benzodiazepines and/or had been placed in psychiatric hospitals during their youth were more likely to have children who ended up chronically pharmaceuticalized in early adulthood (Béhague, 2004). Clinicians and public health researchers might interpret this to mean that mental morbidity clusters in families through both biological mechanisms and the very intimate processes of socialization involved in the mother-child relationship, and this is surely part of the picture. Parents and children alike described their households as stressful places permeated by fighting, fear, and heightened forms of control over children's behavior. Rosane's mother, like Alex's and others I knew who suffered from nerves attacks, were intensely preoccupied with violence and other pernicious influences in the shantytown. They tried protecting their children by keeping them indoors as much as possible, only to find this backfiring in the form of growing defiance. This certainly points to the intergenerational social production of distress. Yet what is being passed down is not merely a distressed mode of life, but whole routines of care and self-making. These routines are as "familial" as they are institutional, psychiatric, and societal. Though childhood difficulties are being framed in newer diagnostic categories such "inattention" and "behavioral problems," these youth are undoubtedly enacting a historically entrenched form of institutional psychiatry that has long viewed the psyche of the "underclass" in somatic and behavioral terms.

Why, then, do I refer to these intergenerational dynamics as "medico-political histories" in the title of this subsection? Why are these not simply outgrowths of medical histories? Why do I argue for an analytical narrative that does not fall into the trap of attributing full explanatory force to psychiatry and expertise? Because, to restate, psychiatric routines are not deterministically "made" by experts and clinicians; they are, as will be further exemplified below, co-produced within the fabric of everyday life.

Rosane and Alex's mothers were passing down not just the psychiatric experiences, values and languages they had internalized in their own youth. They were also imparting their personal politics, their modes of contestation and their concerns with social injustice. Though hospitalized and pharmaceuticalized for their nerves attacks, their desire for medicated relief was in no way de-politicizing. Rather, discussions about the origins of their long-standing nerves problems, about why they needed benzodiazepines in the first place, and about the suitability of psychiatric care, nearly always fused with discussions of poverty, inequity, and discrimination. Rosane and Alex's mothers were, like their children, seeking in psychiatry a public venue and an authoritative if contested language within which to make their lives and perspectives known (Duarte, 1986; Scheper-Hughes, 1992).

Thus, at the same time that psychiatric care was itself an object of contestation, it was also the case that these complex histories of psychiatric "care" opened up a space for families to work through an array of personal, political and moral conundrums and uncertainties. More so than other mothers I knew, Rosane and Alex's mothers' personal stories of nerves attacks and psychiatric interventions flowed seamlessly into discussions of a rapidly changing and unsettling world. They worried about the ways in which the "modern values" their children 
were encountering in school gave them unreasonable license to skirt their budding adult responsibilities. They complained of democratizing pedagogies in schools that encourage "talk" and "equal exchange" rather than "proper discipline," and they argued that the psychological focus on "adolescent" self-analysis and improvement so readily found nowadays disempowered parents, adding a new set of emotional challenges to family life. They often justified their support for a more disciplined and rapidly paced style of parenting by emphasizing the need to learn to overcome hardship and recalling the origins of their own troubles: traumas from migration, rapid downward mobility, family deaths, parental alcoholism and domestic violence. While they worried that their children were too immature relative to their age, they did not seek to temper their children's development by adopting the ideal of a gradual and institutionally guided "adolescence." Their rejections of "modern" child-rearing values were often underpinned by the sense that these values were classist and impractical.

Child-rearing routines and intergenerational conflict within families thus became a kind of "stage" for the playing out of larger societal problems and for the "practicing" of an array of polarizing politics - between parent and child, family and school, family and psychiatric care, and between the shantytown and the world of the middle class. Within this stage, the psychological language of development, adolescent emotional well-being and suffering became "good to think with" metaphors. Alex and Rosane, for example, did not appreciate being kept indoors and pressured to become adults before they felt ready, nor did they appreciate the tense ways in which their parents' imperatives were imparted, and they used framings of the benefits of slow "adolescent development" to negotiate greater freedoms at home. All the while, they continued rejecting framings of adolescent development and impulsivity in school. Underscoring these multi-layered positionalities, I discovered Alex's desire for military therapeutics was also linked to his desire to escape the heavy-handed nature of his mother's parenting. "Sometimes I wonder if the barracks would actually be any better than here [home]," he reflected, "because if I enter the military, I will just be imprisoned there rather than here. My mother, she's from the times of slavery you know, 'I'm going to put a chain on your leg so you don't go out!' she says. I get so angry sometimes I think I'm going to explode... You can't do this to an adolescent, they need space, and time." In voicing his frustrations, Alex, like other youth, became particularly vested in using notions of generational change and the unique needs of "adolescents" to distance himself from parental control and seek emotional peace. A telling minority of youth such as Alex and Rosane even embraced clearly demarcated youth subcultures, such skate-boarding and gang membership, which they argued were politically motivated and not merely socially deviant, as many adults, they told me, tend to assume. Sharing their parents' intense skepticism of middle class values, their rejections of all forms of authority were starkly polarizing and in a conflation of age and class, included virtually all adults. Ironically, such intensified defiance reinforced their mothers' concerns that their children were experiencing "developmental stagnation," that they would struggle to become responsible adults and needed more behavioral containment. As Alex's mother stated several times in justifying her "military-style" parenting, "He needs clear rules and discipline. He needs to face up to becoming an adult. He is such a child, his [growth is] stuck." Time and again I found parents referring to this notion of "developmental stagnation" and though it bears close resemblance to the conservative form of ego psychology 
that psychiatrists had told me slips easily into chronic pharmaceuticalization, its enactment in everyday family life was intensely manifold.

Let me return to the fact that chronically pharmaceuticalized "psychiatric" forms became attached to "these" turbulent adolescences and not others. Recall the key insight provided by the comparative perspective employed in this paper: most low-income youth walked away from the recommendation that they attend therapy, and their rejections were largely totalizing, for they also tended to leave school. Others used a temporary form of pharmaceuticalized therapy to assist them in their upwardly mobile trajectories. What I have shown here is that Alex's and Rosane's pharmaceuticalized conclusions were intensely multifaceted: co-produced by the interplay of maternal histories of psychiatric care, generational conflicts, and underlying moral debates surrounding child-rearing and "modern" values.

\section{...is not air-tight}

But is the interplay of forces leading to pharmaceuticalization always air-tight? Is it not possible, even if only in exceptional moments, to break through the cracks? I began exploring this question in a paper concerned with a small and somewhat exceptional subset of young people who experienced therapeutic trajectories that eventually became highly personally and politically meaningful, as well as life-changing. At first glance, these young people appeared to experience life in the same way as did Alex and Rosane. Also of low income backgrounds and most often living in shantytowns, they were critical of middle class norms and struggling to make sense of the injustices that surrounded them. Like Alex and Rosane, they too felt initially criticized by teachers' referrals to therapy and the kinds of behavior-based diagnostic categories they were labelled with in the process. Yet over time, what evolved therapeutically was far from the slippery slope of the medicated holding patterns described above. Instead, references to clear-cut diagnoses were avoided, talk of specific symptomologies came and went, social etiologies were considered alongside emotional and psychological ones, and all the while, therapeutic suggestions remained pragmatic, socially sensitive, empowering, and rarely chronically pharmaceuticalized (Béhague, 2009).

At the time of this publication, I had not fully understood how these empowering therapeutic trajectories managed to skirt pharmaceuticalization. However, set within the broader comparative analysis traced in this paper and a clearer sense of how these trajectories could have evolved, it became clear to me that what distinguished these exceptional therapeutic processes was the productive "working through" of clinical, social, political, and intergenerational polarizations. This "working through" was not at all a placating or depoliticizing process. Rather, the contested nature of the diagnostic languages that young people had encountered provided them (and their therapists) with a useful anchor, a "good-to-think-with" and good-to-negotiate-with politicizing tool. Therapists and patients came together as bricoleurs par excellence. What materialized was a sustained "politicizing clinic," a place to rehearse and address social, class, and interpersonal conflict. Young people brought forth a slew of stories to the therapeutic encounter - allegations that teachers had unfairly singled them out, stories of micro-class conflicts in their neighborhood, and fears of violence in the shantytown. And therapists responded with forthright sensitivity, at times 
sustaining the rehearsing of conflicts and using this as mirror of ongoing struggles of the outside world. Several youth told me with a combination of bewilderment and burgeoning self-confidence how the therapist they had come to know - always so clearly a member of the upper-middle class - had asked thoughtful questions about their lives, showing deference for a world they acknowledged was ruthless and different from their own. Therapists' empathetic acknowledgement of the ubiquitous nature of class struggles and classism was, I believe, the crux of what eventually became a positive and even transformational therapeutic experience that translated into both emotional betterment and actual political engagement, which many youth seek but ultimately felt alienated from.

At the time of this publication, my central analytical focus stressed "purposefully equivocal" nature of Brazilian psychiatry practice (Béhague, 2009). ${ }^{5}$ Notwithstanding the importance of clinical practice and therapeutic approaches, however, I came to realize that the "politicizing clinic" is the end result of something much larger. The "both/and" way of "living equivocality" that youth embraced was not simply (or even primarily) imparted through clinical or expert practices, for it is also a distinguishing feature of "Brazilian" cultural, social, and political life (Escobar, 1992). What's more, though some young people actively and powerfully embodied equivocality, it also generated uncertainty, the tension of living "between worlds," and a sense of social threat. For young people experiencing and seeking the "politicizing clinic," this "in-between-ness" was actively sought and often became the key motive for continued therapeutic need. In this sense, equivocality was very much incrementally co-produced through a back and forth movement between young people's social thirst for norm-breaking modalities and the continual reconfiguration of therapeutic practice to serve these modalities. All the while, this back and forth remained tempered, avoiding the exhausting polarizing routines of "hegemony" and "resistance" that typically degrade into reductionist forms of pharmaceuticalization.

Flávio was first referred for psychological care in school around the time of his brother's death for what he described as an inability to focus on his studies, behavior problems, and adolescent-induced emotional "outbursts" of aggression. Like so many other youth, he often felt "picked on" by his teachers and the school psychologist, and often rejected the insinuation that anything might be "wrong with him," pointing instead to the obvious difficulties that ensue after the loss of one's brother. Yet he returned to the school psychologist on and off for a year, supplementing this with a two to three month period during which he visited a psychiatrist in public sector outpatient care. Though Flávio took anti-depressants for several months, he attributed his gradual improved sense of well-being to an array of developmental and social processes. Developmentally, for example, he explained that therapy guided him through what he came to consider a "normal" process of adolescent maturation. Instead of rejecting either the diagnostic terms he had first come across (e.g. inattention) or the clinical definition of adolescence within which these were situated, he found meaning in experimenting with what a "Hallesque" storm-and-stress adolescence might offer - a structural and temporal resource for his own self-improvement and a legitimizing rubric within which to explain a myriad of difficult emotions.

At the same time, he remained critical of the upwardly mobile middle class ethos to which this kind of adolescence is tied, and instead modified his version of a therapeutic 
adolescence to include "Freirean" pedagogic values, and specifically, the central need for "critical consciousness." "It's not that you have to lose your charm [graça] when you grow up," he explained, "but you must become aware [tomar consciência] of the fact that you have grown up, that you can't do this or that any more. So you calm down... But that doesn't mean you can't get angry at some of the stuff that happens around here... If there's a serious issue that needs to be discussed, such as when a friend of mine has a serious problem, I can help him, and he listens to me..." As a small collective, young people like Flávio recreated a more politicized version of Stanley Hall's adolescence in ways that moved away from the older languages of psychiatric containment, be it institutional or pharmaceutical, that beset many of their peers, as described above. Therapy became neither an elite aesthetic to be emulated nor a discriminatory structure to be rejected. Rather, in therapy Flávio and young people like him sought, and were offered, a path in-between.

Persisting with his education, Flávio completed more schooling than his socio-economic background would have predicted and by his 18th birthday he was atypically well on his way to a formal-sector job. Even then, he did not depoliticize his position by adopting a self-vindicating narrative of self-improvement as other upwardly mobile youth did. In fact, when his family's income increased, they could have moved away from their shantytown as many families do and yet they remained where they had always lived. Interestingly, Flávio's mother had also experienced heightened nerves attacks in her own youth and she too had struggled with benzodiazepine use, undergoing at one point in her life, psychiatric hospitalization to little avail. However, the emotional tenor of Flávio's relationship with his mother did not amplify and digress into the language of generational conflict or the need to reject "modern life." Again, this did not imply a loss of critical positioning. As he matured, Flávio applied his emerging class politics to a wider gamut of situations. He became a diplomat in the purest sense of the word, negotiating links between shanty and non-shanty worlds, as well as attenuating tensions between families of different class standings within the shanty (Caldeira, 2000). He helped a few of his peers stay in school and away from illicit drug use while also not belittling the worth of their working class roots, their hand-built wooden homes, or their desire to hang out on the streets, skateboarding, playing football, or even befriending local gang members. This was highly significant. As noted above in recounting Alex's mothers parenting style, many shantytown families respond to social insecurity by keeping their children indoors as much as possible. Flávio, in contrast, mediated between the sanctity of "home" and the threats of the "street," re-legitimizing the latter (Da Matta, 1985).

It is important to underscore that young people such as Flávio did more than demonstrate a "tempered attitude." In focusing quite precisely on how they compared with the two pharmaceuticalized trajectories outlined at the onset of this paper - one middle-class and psychodynamic and the other a chronic response to the strains of destitution - I noticed that youth such as Flávio were positioning themselves in ways that countered the normative patterns they were observing in their social worlds. They were astute "para-ethnographic" observers (Holmes, Marcus, 2008), and with a keen sense of how social life is patterned, they explicitly took on positions that defied these patterns. As noted, for example, though Flávio's personal situation improved and he hoped to attend college, he did not want to migrate away from the shanty, as most upwardly mobile youth do. This is curious from the 
perspective of both the middle class and shantytown dwellers, many of whom reject the elitism of higher education. He also became politically active in his school, running to be his class representative, a job generally desired only by middle class students (or the aspiring middle class) and sometimes actively shunned and rejected as "corrupt" by working class students. Significantly, Flávio ran for class representative while avoiding being criticized by his peers on either side of the class divide and while becoming politically active in his shanty as well, contributing to his local shantytown neighborhood. He lived in two worlds that to most seem resolutely mutually exclusive.

How did young people like Flávio acquire these faculties? Who are their "families" in the broadest multigenerational sense of the word? How have these families' histories been situated over time in ways that have given birth to their positionalities as exceptions and exceptional? I have as yet only a partial answer to these questions, but it is one that points in an interesting direction. Flávio's parents were also keen observers of the patterning of social life, and they too modified their position according to what they observed. Flávio's father, Emilio, proudly told me once how his own father had been a founding member of their shantytown's neighborhood association in which Emilio played a central role. These associations were created and took hold mostly in the 1960s, 1970s, and 1980s, at the time of most recent Brazilian dictatorship and together with other grassroots civil society entities, they were instrumental in fomenting the popular momentum that contributed to ousting the dictatorship (Alvarez, 1997). Today, they continue to be active in most shantytowns and their members carry out a range of social, civic, and politicizing activities, from street cleaning to organizing bingo games to lobbying, quite effectively sometimes, for electricity, improved clinical outreach, or a proper sewage system.

Leaders of these associations are often in a delicate social and political position, for in negotiating with official institutions and persons of (middle-class) authority, they are also more liable to be denigrated by shantytown members wary of any sort of dealings with people from such institutions. "For many people here in the shantytown," Emilio told me in frank terms, "the doctor or teacher or researcher who comes here to visit us is only interested in us for the very same corrupt reasons as politicians." Yet like Flávio, Emilio told me of the many ways he stood his ground and followed his own father's footsteps, fostering a sense of community among his shantytown neighbors, while also developing close and even intimate friendships with the physician in his local clinic, with the director of his children's school, and even with local politicians who came to canvass votes.

"It's true politicians come here to with promises to 'buy' votes, and they often walk away and never think about us again," he explained, "but like my father told me, they're not all that way; they're people just like us. Brazil won't get out of this mess until we all realize this." Even something as seemingly mundane as the "street cleaning" days he organized on behalf of his neighborhood association became an opportunity for him to question polarizing forms of political engagement (Holston, 2008). "People always say they won't participate in street cleaning because the city should be recognizing our community as legal and legitimate. But I talk about this a lot - we can still fight for our rights while learning to take care of ourselves." Emilio went out of his way to nurture a nuanced approach to every one of his relationships, familial and otherwise, and in every facet of life, including the more intimate 
domain of emotional life. He was no stranger to severe mental distress. As he recounted the time when his wife had been hospitalized for debilitating nerves attacks after the birth of their first child, he had little positive to say about that experience or about "those benzos" that seemed to only make things worse. But he and his wife persisted in seeking psychological and psychiatric care, often on their own terms and in ways that planted the seeds for the politicizing clinical experience that their son Flávio would in the future help to construct.

\section{Final considerations}

To suggest, as this paper has, that clinical practices are drops in a much larger ocean, so fully constitutive of this ocean that it makes little sense to speak of them as separate entities, is of course well recognized. Scholars in science studies, anthropology and sociology, have long called attention to the limitations of teleological "before and after" framings of science that privilege the expert "markers" of categories and their clinical "implementers." Moving beyond "constructivist" frameworks, this scholarship has called for a shift in focus from studying ways of knowing, first and foremost, to studying the ways in which objects of scientific attention are co-produced, enacted and performed by an array of actors (Latour, 1987; Lock, Kaufert, 1998; Hacking, 1999; Mol, 2002).

Following this analytical framing, this paper has explored how different adolescent trajectories, some more recognizably "biopsychiatric" and problematically pharmaceuticalized than others, have arisen through the co-production of clinical practices with subject-making practices, developmental trajectories, and broader social formations. Rather than attribute the rise of pharmaceuticalized adolescence to the emergence of biomedical epistemes and the globalization of biopsychiatry, I have explored the indirect and contingent circumstances through which these bioepistemic forms take shape and persist. Extending the field of "contingencies" that account for pharmaceuticalization to the historical and intergenerational, I have explored how contemporary clinical enactments of adolescence animate - and potentially transform - historic problematics relating to education, employment, politics, classism, feminism, livelihood, inequity, parenting, kinship, and upward mobility.

To theorize how epistemic forms arise not only out of ideological battlegrounds in and about science and the clinic, but also in and through these broader themes, is particularly important for the Brazilian context. As noted, black and white bifurcations are not - and have not been - as meaningful a mode of expression in Brazilian science, medicine, or society as in much of the Anglophone world (Plotkin, 2001, cf. Luhrmann, 2000). In this sense, the Brazilian case demands, perhaps more than in other localities, a framing that can attend to the ways psychiatry, in concert with the everyday, can generate new insights and more radically transformative therapeutic approaches. Even so, there are also instructive elements here for ethnographies of psychiatry outside of Brazil. Simply put: though the historic trajectories through which transformative therapeutic modalities emerge may be exceptional, minimal, and at times seemingly "invisible," greater attention to "exceptionalities" may provide a much-needed complementary approach to more classical analyses centered on the institutionalized intersections of psychiatry, power, and knowledge. 
What broader social forces encourage and discourage not just bioreductionism but also its alternatives? There are some indications from what I have described in this paper that part of the answer to this question lies in how the engines of polarization - polarizations that are medical as well as political, emotive, and social - create the conditions for reductionist ways of acting and thinking. Attention to how such polarizations are at times weakened calls into question assumptions about "epistemic resistance" as the key or only modality through which bioreductionism can be questioned. What is central here is not simply the equation of a bioreducionist episteme with a certain way of thinking about the brain, pathology, and pharmacological solutions, but deeply entrenched social, moral, economic histories that create both a desire for this episteme and the impetus for its dismantling.

\section{ACKNOWLEDGEMENTS}

Dominique Béhague was the recipient of a US National Science Foundation doctoral fellowship from 1997 to 2001 and from 2005 to 2011, a postdoctoral fellowship from The Wellcome Trust (Grant no. GR077175MA). The ethnographic portion of the 1982 Pelotas cohort study was funded by The Wellcome Trust, the World Health Organization, the Pan American Health Organization, the European Union, and Programa Nacional para Centros de Excelência (Pronex). Dominique Béhague thanks the Department of Social Medicine in Pelotas for supporting this research in manifold ways; two anonymous reviewers for their astute feedback; and Elizabeth Davis, Li Zhang and all participants of the SAR Seminar "Questioning the 'Global' in Global Psychiatry" for the brilliant and incisive comments on a previous version of this paper.

\section{NOTES}

${ }^{1}$ I selected this group of young people randomly from an ongoing epidemiological birth cohort study initiated in 1982 by colleagues at the Federal University of Pelotas (Victora, Barros, 2006). Fieldwork, comprised of participant observation and repeated semi-structured and informal interviewing with youth and their families, was conducted by myself, another anthropologist, and four research assistants (see Victora et al., 2003; Béhague, Gonçalves, Victora, 2008, for methodological and analytical details). Random sampling was used not to conduct probabilistic analyses, but to capture an array of life experiences, including those of particularly isolated youth.

${ }^{2}$ Of the 96 youth in my ethnographic sample, 19 were prescribed a psychotropic medication at some point in their life. The six who used medications in a temporary way were upper- or middle-class, whereas the 13 who entered into stagnating medicated therapeutics were from low-income families. The socio-economic distribution of these two types of adolescence proved to be salient in the larger epidemiological sample of the 1982 cohort, and it was also the case that low-income youth were more likely to use pharmaceuticals for longer periods (Béhague, 2004). What is more, a study published in 2006 found that though the wealthy consume psychotropics in greater proportions than the poor, from 1994 to 2003, there was a reduction in use amongst those with more education and an increase in use amongst those with very little education (Rodrigues, Facchini, Lima, 2006).

${ }^{3}$ Military service of one year is required of all young men of 18 years of age, but it is a requirement that the elite often easily avoid, that only the middle class actually comply with, and that those with less than eight years of education wanting to serve must actively seek. Few of the young men in question had attained the required eight years of education and so they would have to work extra hard to be accepted, making their entry into military life all the more meaningful.

${ }^{4}$ This may also help explain why these young people did finally return to therapy in adulthood and why they did not fade away as do many young people who feel denigrated and stigmatized by psychological interventions.

${ }^{5}$ As historians have shown, psychoanalysis in the Southern Cone regions of Latin America has long demonstrated a high tolerance for ways of reasoning that encourage acceptance of ambiguity; thus, psychoanalysis has also not always defined itself in black and white terms as the opposite of biologizing, behaviorist or pharmaceutical logics, as has largely been the case in the United States and the United Kingdom (Plotkin, 2001). 


\section{REFERENCES}

ALVAREZ, Sonia E.

Reweaving the fabric of collective action: social movements and challenges to "actually existing democracy" in Brazil. In: Fox, Richard. G.; Starn, Orin. Between resistance and revolution: cultural politics and social protest. New Brunswick: Rutgers University Press. p.83-117. 1997.

BÉHAGUE, Dominique.

Taking pills for developmental ails in Southern Brazil: the biologization of adolescence? Social Science \& Medicine, v.143, p.320-329. 2015.

BÉHAGUE, Dominique.

Psychiatry and politics in Pelotas, Brazil: the equivocal uses of "conduct disorder" and related diagnoses. Medical Anthropology Quarterly, v.23, n.4, p.455-482. 2009.

BÉHAGUE, Dominique.

Psychiatry and military conscription in Brazil: the search for opportunity and institutionalized therapy. Cult Med Psychiatry, v.32, n.2, p.194-218. 2008.

BÉHAGUE, Dominique.

The shaping of adolescent pathology in the wake of Brazil's new democracy. (Doctoral Thesis) McGill University, Montreal. 2004.

BÉHAGUE, Dominique et al.

Taming troubled teens: the social production of mental morbidity amongst young mothers in Pelotas, Brazil. Social Science \& Medicine, v.74, n.3, p.434-443. 2012.

BÉHAGUE, Dominique; GONÇALVES, Helen; VICTORA, César.

Anthropology and epidemiology: learning epistemological lessons through a collaborative venture. Ciência \& Saúde Coletiva, v.13, n.6, p.1701-1710. 2008.

BIEHL, João; LOCKE, Peter.

Deleuze and the anthropology of becoming. Current Anthropology, v.51, n.3, p.317-351. 2010.

BOURDIEU, Pierre.

Distinction: a social critique of the judgement of taste. London: Routledge; Kegan Paul. 1984.

CAIRNS, Robert.

The making of developmental psychology. In: Damon, William; Lerner, Richard M. Handbook of child psychology: theoretical models of human development. v.1. New York: John Wiley. 1998.

CALDEIRA, Teresa P.

City of walls: crime, segregation and citizenship in São Paulo. Berkeley: University of California Press. 2000.
COSTA, Jurandir Freire.

História da psiquiatria no Brasil. Rio de Janeiro: Documentário. 1976.

DA MATTA, Roberto.

A casa e a rua: espaco, cidadania, mulher e morte no Brasil. São Paulo: Brasiliense. 1985.

DOUGLAS, Mary.

How institutions think. Syracuse: Syracuse

University Press. 1986.

DUARTE, Luiz Fernando Dias.

Person and psychologization in Brazil: a study in moral regulation. Journal of Latin American Anthropology, v.4-5, n.2-1, p.142-171. 1999-2000.

DUARTE, Luiz Fernando Dias.

Da vida nervosa nas classes trabalhadoras urbanas. Rio de Janeiro: Jorge Zahar. 1986.

DURHAM, Deborah.

Disappearing youth: youth as a social shifter in Botswana. American Ethnologist, v.314, n.4, p.589605. 2004.

ESCOBAR, Arturo.

Culture, practice and politics: anthropology and the study of social movements. Critique of Anthropology, v.12, n.4, p.395-432. 1992.

FREIRE, Paulo.

Pedagogy of the oppressed. New York: The

Continuum Publishing Company. 1990.

GILLIS, J.

Youth and history: tradition and change in European age relations, 1770-present. New York: Academic Press. 1981.

HACKING, Ian.

The social construction of what? Cambridge: Harvard University Press. 1999.

HALL, G. Stanley.

Adolescence: its psychology and its relation to physiology, anthropology, sociology, sex, crime, religion and education. London: Sidney Appleton. 1904.

HEALY, David.

The antidepressant era. Cambridge: Harvard University Press. 1997.

HEILBORN, Maria Luiza; BRANDÃO, Elaine Reis; CABRAL, Cristiane.

Teenage pregnancy and moral panic in Brazil. Culture, Health and Sexuality, v.9, n.4, p.403-414. 2007.

HOLMES, Douglas; MARCUS, George. Cultures of expertise and the management of globalization: toward the re-functioning of ethnography. In: Ong, Aihwa; Collier, Steven J. 
Global assemblages: technology, politics, and ethics as anthropological problems. Oxford: Blackwell. 2008.

HOLSTON, James.

Insurgent citizenship: disjunctions of democracy and modernity in Brazil. Princeton: Princeton University Press. 2008.

JASANOFF, Sheila.

Genealogies of STS. Social Studies of Science, v.42, n.3, p.435-441. 2012.

LATOUR, Bruno.

Science in action: how to follow scientists and engineers through society. Cambridge: Harvard University Press. 1987.

LÉVI-STRAUSS, Claude.

The savage mind. Chicago: University of Chicago Press. 1966.

LOCK, Margaret; KAUFERT, Patricia. Introduction. In: Lock, Margaret; Kaufert, Patricia. Pragmatic women and body politics. Cambridge: Cambridge University Press. 1998.

LUHRMANN, Tanya Marie.

Of two minds: the growing disorder in American psychiatry. New York: Picador. 2000.

MOL, Annemarie.

The body multiple: ontology in medical practice. Durham: Duke University Press. 2002.

PLOTKIN, Mariano B.

Freud in the Pampas: the emergence and development of a psychoanalytic culture in Argentina. Stanford: Stanford University Press. 2001.
RODRIGUES, Maria Aparecida P.; FACCHINI, Luiz Augusto; LIMA, Maurício Silva de. Modifications in psychotropic drug use patterns in a Southern Brazilian city. Revista de Saúde Pública, v.40, n.1, p.107-114. 2006.

SCHEPER-HUGHES, Nancy.

Death without weeping: the violence of everyday life in Brazil. Berkeley: University of California Press. 1992.

SOUSA, Paulo Luís Rosa; ABUCHAIM, Sérgio Roberto.

Rotas psicanalíticas. Pelotas: Editora da

Universidade Católica de Pelotas. 1994.

TENORIO, Fernando.

A reforma psiquiátrica brasileira, da década de 1980 aos dias atuais: história e conceito. História, Ciências, Saúde-Manguinhos, v.9, n.1, p.25-59. 2002.

TURKLE, Sherry; PAPERT, Seymour. Epistemological pluralism: styles and voices within the computer culture. Signs, v.16, n.1, p.128-157. 1990.

VICTORA, César; BARROS, Fernando.

Cohort profile: the 1982 Pelotas (Brazil) birth cohort study. International Journal of Epidemiology, v.35, p.237-242. 2006.

VICTORA, César G. et al.

The Pelotas (Brazil) birth cohort study, Rio Grande do Sul, Brazil,1982-2001. Cadernos de Saúde Pública, v.19, n.5, p.1241-1256. 2003. 